\title{
Visita de Deus na cidade de Jerusalém: juízo e salvação
}

\author{
God's visit to the city of Jerusalem: Judgment and Salvation
}

\author{
VICENTE ARTUSO \\ PATRÍCIA ZAGANIN CAMILO ROSA
}

\section{Resumo}

As visitas de Deus ao seu povo são constatadas nas Sagradas Escrituras como eventos em que Deus se manifesta para trazer benefícios ou também juízo e punição. $O$ objetivo desta pesquisa é analisar o verbo visitar, no hebraico (Tָָּּקָד), no Antigo

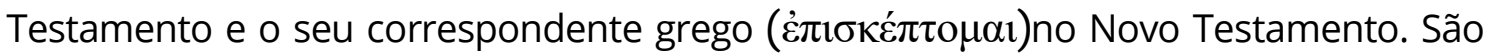
verbos que os autores empregaram para registrar as intervenções divinas em Jerusalém. Pretende-se mostrar os contrastes na vivência religiosa do povo, ora fiel ora infiel, o que determina a revelação de Deus como juiz que visita seu povo para socorrer e salvar ou para punir e castigar. Partimos de textos proféticos de Juízo sobre Jerusalém, para destacar no Novo Testamento a salvação pela visita de Deus em Jesus. Muitos reconhecem a presença de Deus nas ações benéficas que ele realiza. Porém Jesus se tornou também sinal de contradição para os que o rejeitam atraindo o juízo. Assim o artigo mostra os conflitos e resistências diante da visita salvadora de Jesus. Finalmente o estudo conclui com a hermenêutica pastoral da cidade.

Palavras-chave: Visita. Cidade. Salvação. Deus. Compaixão.

\section{Abstract}

God's visits to his people are seen in the Holy Scriptures as events in which God manifests himself to bring benefits or also judgment and punishment. The aim of this

\footnotetext{
a Pontifícia Universidade Católica do Paraná (PUCPR), Curitiba, PR, Brasil. Doutor em Teologia Bíblica, e-mail: vicenteartuso@gmail.com

b Pontifícia Universidade Católica do Paraná (PUCPR), Curitiba, PR, Brasil. Mestra em Teologia, e-mail: patriciazaganin@hotmail.com
} 
research is to analyse the verb to visit, in the Hebrew (פּ⿱

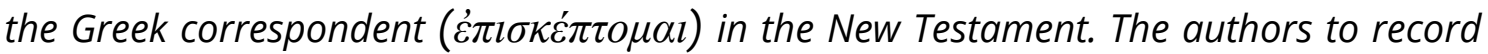
divine interventions in Jerusalem use these verbs. It is intended to show the contrasts in the religious experience of the people, sometimes faithful and sometimes unfaithful. This alternation determines the revelation of God as a judge who visits his people to help and save, or to punish and castigate. We started from prophetic texts of Judgment on Jerusalem, to highlight in the New Testament the salvation by the visit of God in Jesus. Many recognize the presence of God in the beneficial actions he performs. But Jesus also became a sign of contradiction for those who reject him by attracting judgment. The article shows the conflicts and resistances facing the saving visit of Jesus. Finally, the study concludes with a pastoral hermeneutics of the city.

Keywords: Visit. City. Safeguard. God. Compassion.

\section{Introdução}

O presente estudo tem por objetivo interpretar o sentido da "visita de Deus", seja para salvar ou para julgar. Para se referir à visita de Deus no Antigo Testamento a Bíblia Hebraica usa o termo paqad (פָָּקד), que ocorre mais de trezentas vezes no Antigo Testamento. Quando traduzido por visitar, o vocábulo quase sempre tem o sentido de "inspecionar" e indica aquela ação que gera, para melhor ou para pior, uma grande mudança na posição de um subordinado. Existem muitos casos em que "visitar" significa infligir ferimento ou causar dano, e assim muitas vezes o verbo é traduzido por “castigar” (Jr 23,2). Nesse caso a visita significa o juízo de Deus. No entanto, num considerável número de casos, está claro que a visitação provoca um resultado favorável.

O termo adotado no Novo Testamento para falar da tão esperada

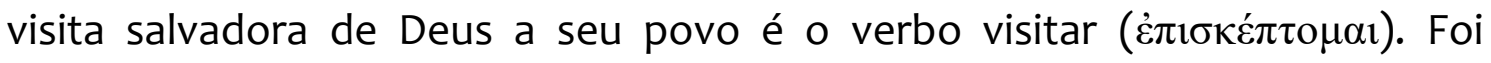
justamente este verbo grego que a Septuaginta utilizou para traduzir o verbo hebraico empregado no Antigo Testamento para designar as visitas salvíficas de Deus ou para relatar fatos semelhantes que demonstrassem intervenções de Deus na história humana.

No Novo Testamento, mais que no Antigo, o conceito de "visita de Deus" recebe o sentido de demonstração benevolente da graça de Deus. Lucas, autor do terceiro Evangelho e dos Atos dos Apóstolos, com muita 
singularidade, emprega o verbo grego para falar das visitas de Deus em benefício do povo (LC 1,68.78; 7,16; 19,44; At 15,14). Ainda que se encontre apenas quatro vezes no seu evangelho, o uso deste verbo, tendo Deus como sujeito, é exclusivo de Lucas.

Beyer (1979, p. 731-749) evidencia que Lucas fez uso do verbo com o significado no contexto da história da salvação que evidencia os benefícios de Deus em favor do povo (Gn, 21,1; Ex 3,16). Se Deus visita o seu povo é para revelar o seu amor e salvar os que se encontram na angústia. Por sua relevância, Dupont (1998, p. 145-149) vê a sua utilização como evocação da imagem do pastor que visita as suas ovelhas (Ez 34,11-16), ajudando a compreender a imagem de Jesus desenhada na teologia lucana.

A investigação em textos do Antigo e do Novo Testamento demonstra que essas intervenções de Deus visam a continuidade do plano de Salvação. O estudo aborda finalmente o alcance pastoral do tema da visitação. Com efeito,

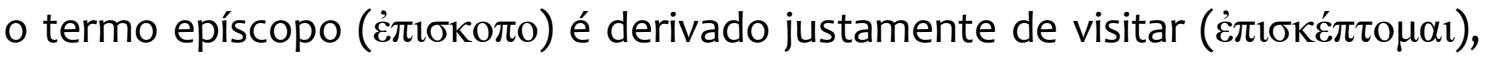
indicando os pastores do povo. A eles cabe visitar, supervisionar e cuidar do povo. Portanto a compreensão do significado desse termo no Evangelho de Lucas e no Novo Testamento contribui para um entendimento atual da função dos líderes, de cuidar do povo em tempos tão difíceis.

\section{Deus visita seu povo}

A história da salvação é muitas vezes apresentada na Bíblia como uma série de "visitas" de Deus a seu povo ou a alguns personagens privilegiados. Deus, que tomou a iniciativa da Aliança e que permanece misteriosamente presente ao desenrolar da história, intervém muitas vezes de modo extraordinário na vida do seu povo, seja para abençoá-lo ou puni-lo. No entanto, na maior parte das vezes, o objetivo é a salvação. Esse olhar de Deus, essas intervenções pessoais, visíveis, são outros tantos sinais de sua presença, de sua ação, da continuidade do seu desígnio salvador e das suas exigências através da fidelidade e da infidelidade do seu povo (LÉONDUFOUR et al., 1984, p. 1093).

As visitas de Deus no desenrolar do plano de salvação manifestam a sua fidelidade às suas promessas ao longo da história. O livro do Gênesis 
narra que Deus apareceu a Abraão, junto aos terebintos de Mambré (Gn 18,19), anunciando-lhe o nascimento de Isaac e a destruição de Sodoma, que denota benefício e punição. No cumprimento deste anúncio o Gênesis informa que "O Senhor visitou Sara, como dissera, e fez por ela como prometera. Sara concebeu e deu à luz um filho a Abraão já velho, no tempo que Deus tinha marcado" (Gn 21,1-2).

José, o último filho de Jacó que encerra o livro do Gênesis, antes de morrer se despede dos seus irmãos recordando a promessa: "Deus vos visitará e vos fará subir deste país para a terra que ele prometeu com juramento, a Abraão, Isaac e Jacó” (Gn 50,24). "Deste modo, a história dos patriarcas se encerra com uma nota de abertura ao futuro" (MURPHY, 2012, p. 127).

O Deus que chamou Abraão para fazer dele pai de uma multidão de povos ( $\ln 12,2$; 17,5) e com esse fim "visitou" Sara tornando-a fecunda intervém de um modo único libertando seu povo da escravidão do Egito. Em sua situação de miséria devido à opressão do faraó, o povo clamou a Deus por libertação. Deus tomou a decisão de intervir em seu favor, viu seu sofrimento e ouviu o seu clamor, por isso desceu para libertá-los da escravidão e conduzi-los para uma nova terra, terra de leite e mel (Ex 3,7-8). A libertação do povo escolhido da escravidão no Egito (Ex 3,16; 13,19) será sempre lembrada como a visita de Deus por excelência no Antigo Testamento.

\section{O verbo paqad}

Na Bíblia Hebraica a raiz pqd (פקד) pode ter diversos significados e é a mais empregada para narrar as visitas de Deus. De acordo com Harris, Archer e Waltke (1998, p. 1228), o seu sentido básico é o de "supervisionar", tanto na forma de inspecionar quanto de tomar providências com a finalidade de obter uma mudança considerável nas circunstâncias de um subordinado. Este verbo ocorre cerca de mais de trezentas vezes no Antigo Testamento e chega-se a afirmar que "provavelmente não exista nenhum outro verbo hebraico que tenha dado tanta dificuldade aos tradutores quanto o verbo pqd” (HARRIS; ARCHER; WALTKE, 1998, p. 1228). Quando é traduzido por "visitar", o vocábulo quase sempre tem o sentido de "inspecionar" e indica 
aquela ação que gera, para melhor ou para pior, uma grande mudança na posição de um subordinado.

Segundo Schökel (1997, p. 544-545), visitar (דָָּּקד) “tem significado básico de inspecionar, vigiar" que pode ter tanto um valor positivo ou negativo para quem é inspecionado. Quando o significado de inspecionar for positivo, o sentido é de "atender, guardar, cuidar, proteger, ocupar-se, visitar; encarregar-(se), encomendar, nomear encarregados”. Assim, em sentido positivo, “ocupar-se de" aparece em Gn 21,1, quando Deus “visita” Sara e cumpre a promessa de uma descendência feita a Abraão, o pai da fé; ainda em Gn 50,24, quando José, antes de morrer, se despede de seus irmãos recordando a promessa que Deus fez aos patriarcas de uma futura "visita" libertadora. "Visitar" aparece em 1Sm 17,18, quando o jovem Davi faz uma "visita" aos seus irmãos, em campo de batalha, leva-lhes pão e ocupa-se, conforme lhe "encarregara" seu pai Jessé, em ter informações sobre a saúde deles. O SI 65,10 demonstra o "cuidar" de Deus para com os seres humanos por meio do seu zelo com toda a criação. O profeta roga pela "proteção" de

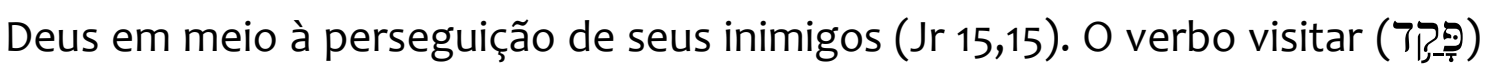
também pode ter o significado de "nomear encarregados", como, por exemplo, José (Gn 40,4) e Aarão (Nm 3,10).

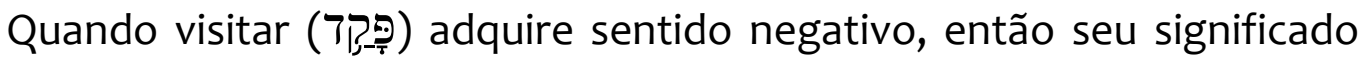
será "exigir contas, indagar, castigar" (SCHÖKEL, 1997, p. 544-545). São os casos como, por exemplo, em Ex 32,34, quando Deus “pede contas" ao povo e promete "castigá-los" por sua infidelidade à Aliança, a idolatria ao bezerro de ouro, e Sf 1,8-9, quando Deus fará uma intervenção especial, para “castigar” os príncipes de Judá por suas ações fraudulentas e violentas.

\section{O verbo episképtomai}

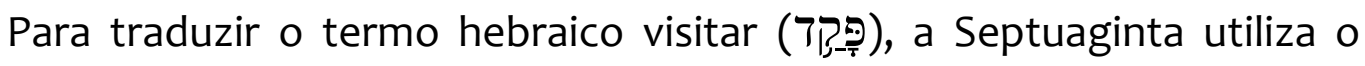

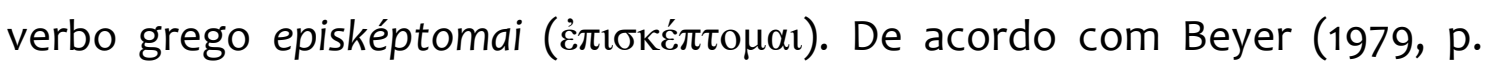

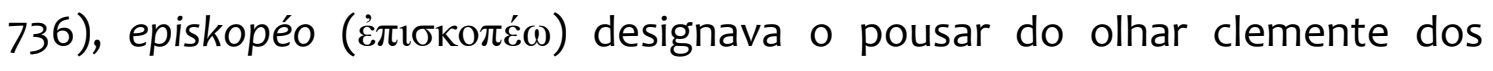
deuses. Na Septuaginta, adquire toda uma série de novos significados, assumindo um profundo sentido religioso. 
O verbo visitar na forma grega, assim como na bíblia hebraica, possui diversos significados. Pode ocorrer no sentido de "visitar" (SCHOTTROFF, 1978, p. 594), como é o caso de Jz 15,1, quando Sansão “visita” sua mulher, e em Eclo 7,35, quando aconselha: "Não temas visitar doentes, porque serás amado por isso". Pode igualmente ter o significado de "ocupar-se de alguma coisa”, ou seja, "cuidar", como na imagem do pastor que vela seu rebanho nos textos de Jr 23,2; Zc 2,16; Ez 34,11.12. Recebe também grande importância no sentido de "passar em revista, ser revistado" e, neste sentido, só em Nm 14 aparece quarenta e três vezes, como nos informa Beyer (1979, p. 737).

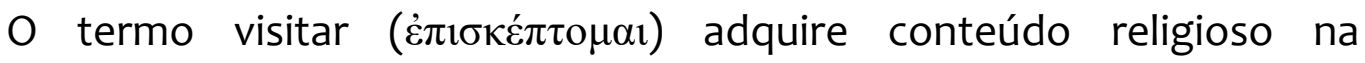
Septuaginta apenas quando o assunto é Deus. Os vários significados se resumem para assinalar o agir divino, no qual o Senhor, com uma especial intervenção na vida, manifesta na ira ou na benignidade o seu querer a uma pessoa só, ou a um povo. Quando Deus se reaproxima do povo que reside no pecado e na indigência, e se mostra como Senhor da história, então advém tal "visita". Visita esta que pode cumprir-se em um juízo punitivo, mas também num ato de benigna misericórdia. Todavia, isso acontece de modo que se possa reconhecer uma real intervenção de Deus na história.

O verbo "visitar" pode ser usado na mesma frase no seu duplo sentido, de ação punitiva ou de ação misericordiosa. É o caso, por exemplo, de Zc 10,3: "Contra os pastores se inflamou a minha ira, e os bodes eu vou castigar. Quando o Senhor dos Exércitos visitar o seu rebanho, a casa de Judá, ele os

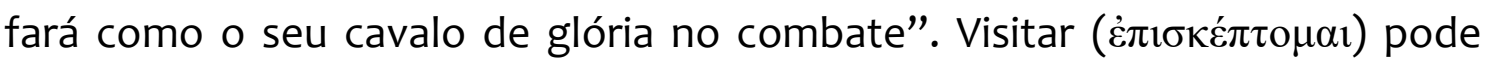
significar "punir, celebrar o juízo", como em Ex 32,34, ou então, a “visita” pode consistir também no fato de que Deus se aproxima com a sua benção no sentido de proteger amavelmente um indivíduo ou um povo.

\section{Visita de juízo e salvação para Jerusalém (Is 29,1-8)}

O texto de Is 29,1-8 é um oráculo de juízo e salvação para Jerusalém, chamada de Ariel. Este nome pode ter dois significados: 'ariel: leão de Deus, indicando a imagem de um leão sobre o Monte de Sião, cercado por pastores (Is 31,4); ou har'el: montanha de Deus. Na segunda opção seria a parte 
superior do altar (Ez 43,15) onde se ofereciam os sacrifícios, seria o "coração do altar" (JENSEN; IRWIN, 2007, p. 505).

$O$ contexto é anterior ao assédio feito pela Assíria em 701 a.C. e evoca a conquista da cidade pelo rei Davi (Is 29,1; $2 \mathrm{Sm} 5,6-7$ ). Portanto, é anúncio da ameaça que está por vir contra a cidade de Jerusalém. A menção às festas ( $v$. 1) pode indicar que as autoridades e o povo festejavam e não se davam conta da gravidade do perigo que estava por vir.

Fala-se do abatimento, da palavra abafada ao pó da terra e a voz como de espíritos debaixo da terra, isto é, de mortos $(29,4)$. São imagens do aniquilamento, de quem é jogado ao pó, no chão da vida.

A cidade será "visitada por YHWH dos Exércitos" $(29,6)$ quando a catástrofe parecer iminente, com os inimigos às suas portas. A visita marcará a ação de Deus em favor do seu povo com sinais cósmicos que lembram as ações de Deus no Egito. E de forma grandiosa, como nos informa o SI 48: "Ele é grande e muito louvável na cidade de nosso Deus" (v.2), "Entre seus palácios Deus se mostrou como fortaleza" (v.4).

Da ameaça de castigo (vv. 1-4) passa-se para uma promessa de salvação e de libertação (Is 29, 5-8). O Senhor visitará a cidade para defendêla daqueles que chegam para atacá-la. Não há dúvida de que esta é também uma mensagem de salvação. Mas a linguagem é ambígua: primeiro vem a ameaça e depois a salvação. Isso pode indicar que a segunda seja uma releitura posterior (CROATO, 1989, p. 177).

\section{Visita no Evangelho de Lucas}

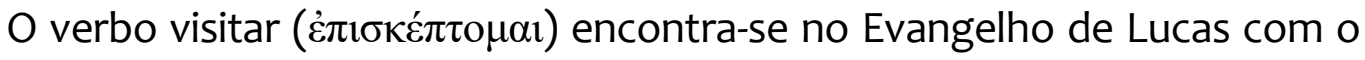
mesmo aspecto de cumprimento de promessa ligado ao cumprimento da descendência ou da libertação do Egito (Ex 3,7-12). Se o Êxodo 15 canta a libertação do povo da escravidão do Egito, caminhando rumo à Terra prometida, Lucas apresenta Zacarias, no cântico do Benedictus, que canta e bendiz o Deus de Israel porque visita e redime seu povo (LC 1,68), por isso a vinda de Jesus, 0 Salvador, é cantada como a visita do Astro das alturas (LC 1,78).

Já em pleno ministério, quando Jesus reanima o filho de uma pobre viúva, é que o novo povo de Deus se une para dar glória porque "Deus visitou 
o seu povo" (Lc 7,16). Porém, tristemente Jerusalém, a cidade da paz, não reconheceu o tempo de Deus presente quando foi visitada (Lc 19,44).

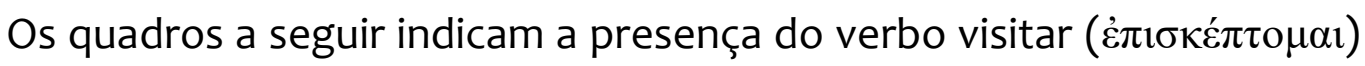
na obra de Lucas (Evangelho e Atos dos Apóstolos). Em todas as ocorrências, trata-se da visita de Deus.

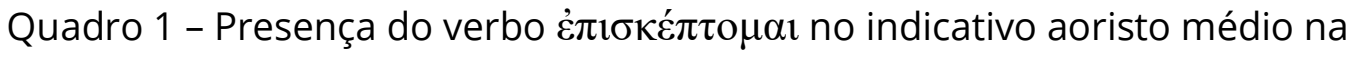
terceira pessoa do singular

\begin{tabular}{|c|c|c|c|c|}
\hline Citação & Texto & Tradução & $\begin{array}{c}\text { Sujeit } \\
\text { o }\end{array}$ & Contexto \\
\hline LC 1,68 & 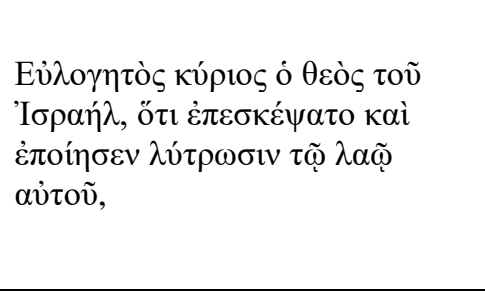 & $\begin{array}{l}\text { Bendito seja o } \\
\text { Senhor Deus de } \\
\text { Israel, que } \\
\text { visitou e fez a } \\
\text { redenção a seu } \\
\text { povo. }\end{array}$ & Deus & $\begin{array}{l}\text { Cântico de } \\
\text { Zacarias (Lc } \\
1,67-79)\end{array}$ \\
\hline LC 7,16 & 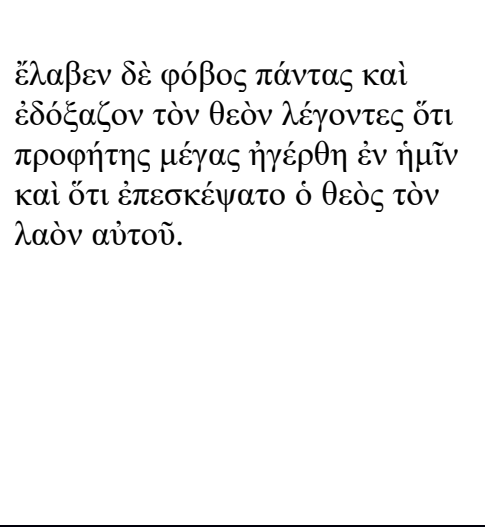 & $\begin{array}{l}\text { Todos pois } \\
\text { ficaram tomados } \\
\text { com medo e } \\
\text { glorificavam a } \\
\text { Deus, dizendo: } \\
\text { "Um grande } \\
\text { profeta se } \\
\text { levantou entre } \\
\text { nós e Deus } \\
\text { visitou o seu } \\
\text { povo". }\end{array}$ & Deus & $\begin{array}{l}\text { Reanimação do } \\
\text { filho único da } \\
\text { viúva de Naim } \\
\text { (Lc 7,11-17) }\end{array}$ \\
\hline At 15,14 & 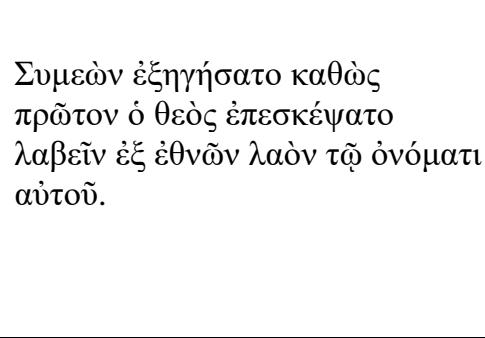 & $\begin{array}{l}\text { Expôs Simeão } \\
\text { como Deus, } \\
\text { primeiro visitou } \\
\text { os gentios, para } \\
\text { tomar dentre } \\
\text { eles um povo } \\
\text { para o seu nome. }\end{array}$ & Deus & $\begin{array}{l}\text { Discurso de } \\
\text { Tiago em } \\
\text { Jerusalém (At } \\
\text { 15,13-21) }\end{array}$ \\
\hline
\end{tabular}

Fonte: MARTINS (2017). 
Quadro 2 - Presença do verbo غ̇ंı pessoa do singular

\begin{tabular}{|c|c|c|c|c|}
\hline Citação & Texto & Tradução & Sujeito & Contexto \\
\hline LC 1,78 & 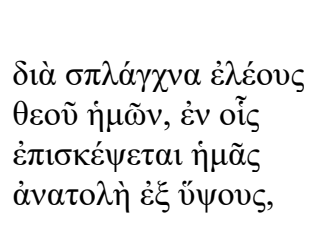 & $\begin{array}{l}\text { Pelas entranhas da } \\
\text { misericórdia de } \\
\text { nosso Deus, pelo } \\
\text { qual nos visita o } \\
\text { Astro das alturas. }\end{array}$ & Messias & $\begin{array}{l}\text { Cântico de } \\
\text { Zacarias (Lc } \\
\text { 1,67-79) }\end{array}$ \\
\hline
\end{tabular}

Fonte: MARTINS (2017).

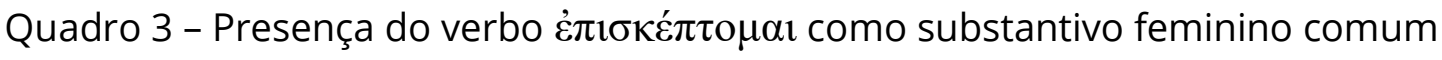
genitivo singular

\begin{tabular}{|c|c|c|c|c|}
\hline Citação & Texto & Tradução & Sujeito & Contexto \\
\hline LC 19,44 & 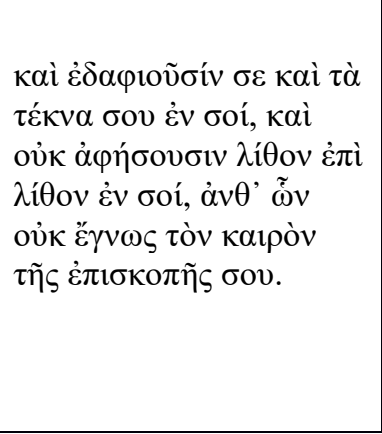 & $\begin{array}{l}\text { E derrubarão a ti e } \\
\text { a teus filhos no } \\
\text { meio de ti, e não } \\
\text { deixarão de ti } \\
\text { pedra sobre pedra, } \\
\text { uma vez que não } \\
\text { reconheceste o } \\
\text { tempo da sua } \\
\text { visita. }\end{array}$ & Jesus & $\begin{array}{l}\text { Lamentação de } \\
\text { Jesus sobre } \\
\text { Jerusalém (Lc } \\
\text { 19,41-44) }\end{array}$ \\
\hline
\end{tabular}

Fonte: Os autores (2021).

O cântico de Zacarias é um hino de ação de graças, porque o Deus de Israel veio visitar o seu povo (LC 1,68). Deus não só tem o seu olhar sobre o povo, mas realiza uma visita favorável, definitiva e absoluta que tem sentido escatológico (BOVON, 2005, p. 153). A visita de Deus exclamada por Zacarias é salvífica e libertadora porque "suscitou-nos uma força de salvação na casa de Davi, seu servo" $(1,69)$. Uma "força de salvação" que é o próprio Jesus, o Messias, e uma libertação que destrói os inimigos e os que odeiam o povo santo $(1,71)$. 
“Visita” de Deus e "salvação" aparecem estreitamente associados no SI 106,4: "Lembra-te de mim, Senhor, por amor do teu povo, visita-me com a tua salvação". No cântico de Zacarias, a relação é muito mais específica: "uma força de salvação" (v. 69). Com referência não a uma salvação teórica, mas à ação salvífica de Deus, personificada em Jesus, esse mesmo verbo voltará a aparecer no v. 78 e, mais adiante, em Lc 7,16 (FITZMYER, 1987, p. 179).

O milagre realizado por Jesus na reanimação do filho da viúva de Naim (Lc 7,11-17) alcança reconhecimento cristológico na grande aclamação do povo que reconhece neste acontecimento que "Deus visitou o seu povo" (LC 7,16) (BROWN, 2004, p. 345).

O discurso de Tiago em At 15,14 mostra como essa visita salvadora de Deus, até então destinada ao povo eleito, está agora voltada aos gentios. Nem todos compreenderam e aceitaram a visita de Deus manifestada em Jesus. Esse não reconhecimento por parte do povo eleito se transforma em ameaça de castigo (LC 19,44). A visita de Deus se torna julgamento histórico. Depois da rejeição de Israel, Deus cria um novo povo entre os gentios.

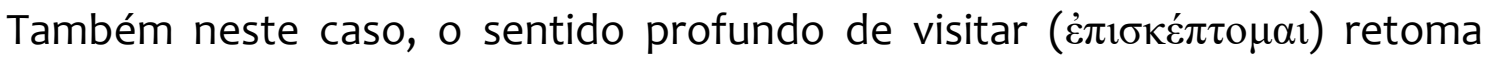
toda a história da salvação.

Como se pode notar, o tema da "visita de Deus" constitui uma expressão predileta do evangelista Lucas (LC 1,68.78; 7,16; 19,44; At 15,14). Cada profeta, cada milagre era acolhido pelo povo de Israel como sinal de particular distinção e predileção (LÄPPLE, 1971, p. 262-263). Com a afirmação “Deus visitou o seu povo" (LC 7,16; 1,68), Lucas demonstra que a autoridade de Jesus não é somente a de um profeta, mas daquele que se apresenta como Messias de Israel, o Filho de Deus, o Senhor da vida e da morte que sabe compadecer-se da necessidade humana. Se o Antigo Testamento fala dessas "visitas" como se fossem intervenções de Deus para abençoar seu povo (Gn 21,1; Ex 3,16; Jr 29,10), em Lucas a visita é obra de sua graça. Jesus se faz presente na história da salvação (OPORTO; GARCÍA, 2006, p. 205) e toda a vida de Jesus é a visita definitiva de Deus aos homens ( $M t$ 28,20).

Além da abordagem de Lucas sobre a visita de Deus ao seu povo, ainda se encontra em seu Evangelho o relato da visita de Maria à sua parenta Isabel $(1,39-45)$. É interessante notar que embora a ação de Maria de ir ao encontro de Isabel seja reconhecida por esta como "visita da mãe do meu Senhor" 
$(1,43)$ o verbo usado por Lucas no texto original para relatar esta atitude de

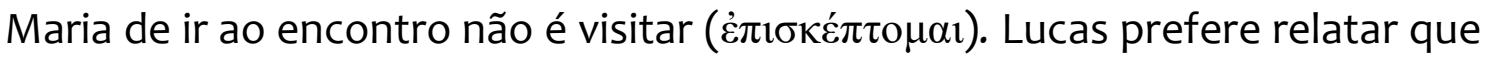

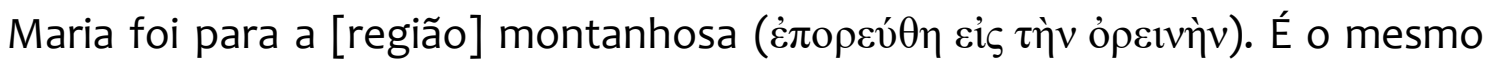
verbo $(\pi \circ \rho \varepsilon v ́ o \mu \alpha \imath)$ indicado para o deslocamento de Jesus de Cafarnaum para $\operatorname{Naim}(7,11 a)$.

Isabel reconhece a ação de Maria como uma "visita" $(1,43)$, segundo a maioria das traduções bíblicas. Porém a expressão no texto original é: " $\mathrm{E}$

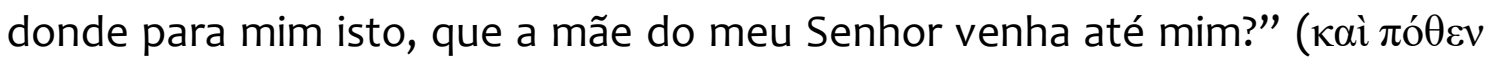

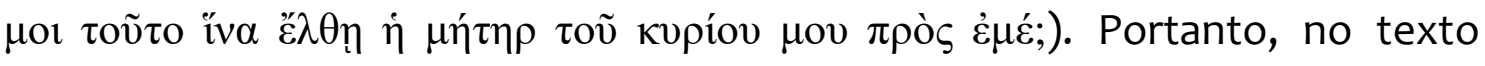
grego não é usado o verbo visitar (NOVO..., 2004, p. 210). Parece que o evangelista tem uma intenção precisa em reservar a utilização do verbo

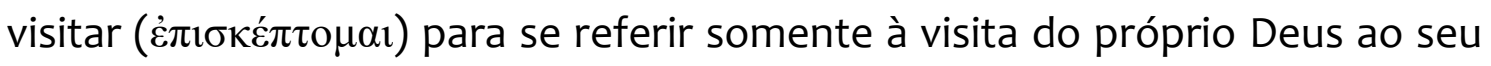
povo, que em seu Evangelho se dá por meio da pessoa de Jesus, o Salvador.

\section{A resistência de Jerusalém em não se converter}

No final da pequena perícope de LC 19,41-44 encontramos mais uma ocorrência relacionada à visita. Porém, não é uma forma verbal e sim um

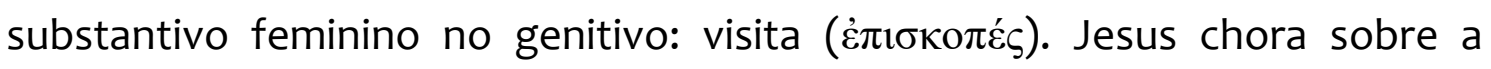
cidade de Jerusalém que não reconheceu o "tempo da tua visita” (v. 44).

A longa caminhada iniciada em 9,51, e que em Lucas ocupa mais da metade do seu Evangelho, chega agora ao seu destino: a cidade de Jerusalém. É interessante notar como ao longo desta caminhada seguidamente a meta é chegar à cidade: "Ele tomou resolutamente o caminho de Jerusalém" (9,51); “Caminhava para Jerusalém” (9,53); "Atravessava cidades e povoados, ensinando e encaminhando-se para Jerusalém” (13,22); “Devo prosseguir meu caminho, pois não convém que um profeta pereça fora de Jerusalém" (13,33); “Como se encaminhasse para Jerusalém, passava através da Samaria e da Galileia" (17,11); “Tomando consigo os Doze, disse-lhes: eis que subimos a Jerusalém" (18,31); “Acrescentou uma parábola, porque estava perto de Jerusalém" $(19,11)$; “Jesus caminhava à frente, subindo para Jerusalém” $(10,28)$.

Depois da boa acolhida pelo povo simples, que estendia suas vestes e cantava hinos alegremente (19,35-40), Jesus estando perto "viu a cidade e 
chorou sobre ela” (19,41), e então profetizou sobre a cidade sagrada: “Ah! Se neste dia também tu conhecesses a mensagem de paz!" (v. 42a). Sua entrada será para trazer a salvação, mas o povo não acolheu e resistiu em não se converter.

O simbolismo teológico da cidade de Jerusalém é maior por causa do Templo do que por sua identificação com a dinastia davídica, pois Jerusalém foi escolhida por YHWH como o lugar para colocar o seu Nome (1Rs 11,13; 2Rs 21,4; 23,27) e Sião é o seu Monte Santo (MCKENZIE, 1984, p. 478). O significado do nome de Jerusalém é justamente "cidade da paz", por isso ela é cantada em tantos Salmos (SI 87; 122; 125; 128; 137). O Salmo 122 reflete bem esta ideia: "Pedi a paz para Jerusalém. Que estejam tranquilos os que te amam! Haja paz em teus muros e estejam tranquilos teus palácios! Por meus irmãos e meus amigos eu desejo: “A paz esteja contigo!”' (SI 122,7-8). Pede-se a paz para a cidade da paz e ao mesmo tempo para quem vem até ela.

Jesus demonstra sensibilidade diante da cidade que ele ama, mas esta resiste e não acolhe a visita de Deus. Aos seus discípulos Jesus havia ensinado a saudar transmitindo a paz (LC 10,5.6), esta mesma paz com a qual saudará seus discípulos depois de ressuscitado $(24,36)$. Jerusalém, a cidade da paz, não é capaz de receber a verdadeira paz, aquele que é a Paz (Ef 2,14). "Jesus chora impotente diante da incredulidade do seu povo nas suas relações, quando vem como Rei de paz" (CENTRO EVANGELIZZAZIONE E CATECHESI “DON BOSCO”, 2002, p. 820). Ou seja: "a cidade cujo nome vai associado à paz não reconhece aquele que a pode levar a esta paz, não reconhece o portador da paz que vem do céu, não reconhece seu 'rei' de paz" (FITZMYER, 2006, p. 113). A cidade está fechada para a graça, resistente à ação salvadora de Deus.

Jesus entra em Jerusalém como Rei. Lucas já havia anunciado que Jesus seria o herdeiro do trono de Davi $(1,32)$. Jesus entra como Rei para cumprir as profecias (Zc 9,9), mas não da forma como entravam os reis da época, ostentando luxúria, pompa e arrogância. Jesus entra humilde, montado num jumentinho emprestado e que em seguida será devolvido (MAZZAROLO, 2004, p. 240).

É tempo oportuno (kairós) da graça de Deus, que em Lucas é sempre positivo, justamente "neste dia” em que Jerusalém está sendo visitada, a cidade 
da paz não sabe receber a paz. "É a ocasião preciosa oferecida por Deus" (BOVON, 2010, p. 57). Na Bíblia, no entanto, o Dia de YHWH comporta sempre dois aspectos: positivos e negativos. A descrição que se seguirá nas profecias de Jesus (vv. 42b-44) faz lembrar fatos passados, como a destruição de Jerusalém sob a Babilônia, em 586 a.C., como também outros acontecimentos quando Jerusalém será destruída pelos romanos, no ano 70 d.C.

A vinda do Messias já havia sido apresentada por Lucas como uma visita de Deus $(1,68.78 ; 7,16)$. A chegada de Jesus em Jerusalém como o Rei Messias deveria ter recebido a acolhida do povo hebreu. No entanto, a recusa será interpretada como um castigo de Deus (CENTRO EVANGELIZZAZIONE E CATECHESI "DON BOSCO", 2002, p. 820). Mas Jesus não exulta por isso; antes, ele chora sobre a cidade. As dores de Jesus têm motivações pessoais, humanas, mas também religiosas. Os habitantes de Jerusalém não souberam ou não quiseram entender o "dia" de Jesus, a visita que estava preparada para a sua cidade (SPINETOLI, 1999, p. 609).

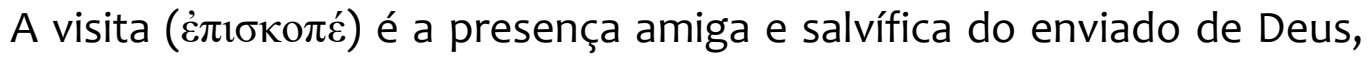
chegou o tempo favorável iniciado com o ministério na Galileia. No entanto, "aqui, por desgraça, o momento positivo enraizado em Deus se choca contra as forças humanas negativas" (BOVON, 2010, p. 57). Jesus visitou Jerusalém, mas os seus habitantes se comportaram como os contemporâneos do profeta Isaías.

A "visita" de Jesus a Jerusalém vai adquirir novo significado. Embora Jerusalém seja a cidade da paz, é também a cidade que "mata os profetas e apedrejados que lhe foram enviados" (LC 13,34), onde o próprio Jesus será rejeitado, condenado e crucificado, e se converterá na cidade de onde sairá a Palavra e o testemunho dos discípulos de Jesus (LC 24,47; At 1,8) (FITZMYER, 2006, p. 114). Há um contraste nos textos de Is 29. Lá se anunciava a ameaça contra a cidade de Jerusalém. A menção às festas (Is 29,1) indicava que as autoridades e o povo festejavam e não se davam conta da gravidade do perigo que estava por vir. No profeta Amós, o dia do Senhor que vem deveria ser salvação, mas se tornou dia da ira implacável (Am 5,18). O povo não percebeu a visita de Deus e não voltou para o Senhor (Am 4,4-12) que os libertou da escravidão (Am 2,10). Em Lc 19,41-44, também o juízo é certo, porém Jesus chora, porque a desgraça não faz parte do seu projeto que é 
salvação e paz. Quando Jesus visitou a sinagoga de Nazaré, ao ler o profeta Isaías, propositadamente anunciou somente o ano aceitável da graça do Senhor, excluindo até mesmo o único dia da vingança (Cf. LC 4,19; Is 61,1-2). Jesus se identifica com o bom pastor, com o Deus pastor do povo de Israel (Jo 10,11; Ez 34,22) que cuida das ovelhas e anuncia a vinda de pastores segundo o seu coração (Jr 3,15), que visitam e cuidam do povo.

\section{Hermenêutica para uma pastoral da cidade}

$\mathrm{Na}$ atual situação de pandemia destes dois últimos anos, os templos precisaram fechar as portas, porém a Igreja, corpo vivo de Cristo, formada por fiéis discípulos e discípulas, se mantém aberta e solidária. São muitos desafios da pastoral na cidade e nesse contexto o desemprego e a fome são os principais problemas. Se não podem ser resolvidos de imediato, ao menos presta-se socorro como ajuda básica aos mais necessitados. Portanto a ação pastoral é o cuidado e atenção aos que sofrem. É também realização de projetos e apoio aos grupos voluntários nas periferias da cidade para promover o bem-estar e a vida.

Portanto a solidariedade não se restringe somente ao auxílio espiritual, mas avança para o socorro material, especialmente aos mais vulneráveis, crianças, populações de rua, imigrantes, presos, pessoas vítimas da violência, pessoas passando necessidades e fome (cf. OLIVEIRA, 2020, p. 266). São pessoas que carecem ser visitadas, e a visitação é o socorro emergencial, especialmente às vítimas do Covid-19. A experiência de receber uma ajuda resulta no reconhecimento e gratidão. Não poucos assim expressam: "Você foi a mão de Deus a me socorrer". Uma demonstração atual da visita salvadora de Deus revela-se na ação solidária promovida pela campanha da Cáritas brasileira lançada em abril de 2020: "Em duas semanas de Ação Solidária, as doações em todo o Brasil contabilizaram $49.064 \mathrm{~kg}$ de itens alimentícios; 22.738 unidades de kits de higiene; 20.449 unidades de roupas e calçados; 4.448 unidades de equipamentos de proteção individual e 3.011 unidades de outros utensílios, como móveis e equipamentos diversos" (AÇÃO..., 2020). A crise suscita a solidariedade entre todos; independentemente dos seus credos, muitos são movidos pela compaixão, 
além das Igrejas: as organizações, empresas, iniciativa privada. Diante desse mundo de sofredores e excluídos, o Papa Francisco, ao convocar o Jubileu da Misericórdia (de 08/12/2015 a 08/12/2016), insistiu que a Igreja deve mostrar ao mundo o rosto de um Deus misericordioso. Na Bula de proclamação do Jubileu escreve:

Misericórdia: é a palavra que revela o mistério da Santíssima Trindade. Misericórdia: é o ato último e supremo pelo qual Deus vem ao nosso encontro. Misericórdia: é a lei fundamental que mora no coração de cada pessoa, quando vê com olhos sinceros o irmão que encontra no caminho da vida. Misericórdia: é o caminho que une Deus e o homem, porque nos abre o coração à esperança de sermos amados para sempre, apesar da limitação do nosso pecado (MV 2).

Em uma homilia em 2014, o Papa falava da visitação e da misericórdia. É com o seu testemunho que o cristão deve mostrar aos outros as mesmas atitudes de Deus que visita o seu povo: a proximidade, a compaixão e a capacidade de restituir a esperança. "Deus visitou o seu povo" é uma expressão que se repete na Escritura, frisou o Papa, relacionando a visita com o episódio evangélico da reanimação do filho da viúva de Naim (Lc 7,11-17). São palavras que têm um sentido especial, diferente de expressões como "Deus falou ao seu povo" ou "Deus entregou os mandamentos ao seu povo", ou ainda "Deus enviou um profeta ao seu povo" (FRANCISCO, 2014). Na afirmação "Deus visitou o seu povo", Francisco vê que há algo mais, uma novidade. Quando Deus visita o seu povo, quer dizer que a sua presença está especialmente ali. Deus visita antes de tudo com a sua presença e proximidade. A pequena cidade sofre a perda de uma criança e uma multidão é solidária. Esse fato move o povo solidário na dor da pobre viúva. A compaixão de Jesus revelou o rosto de Deus misericordioso. Assim, a humanização das relações, mesmo nos grandes centros urbanos, é grande desafio.

Márcio Divino de Oliveira, em seu artigo sobre o cuidado pastoral (2020, p. 261), relata que “Firmada na fé em Cristo, Bom Pastor, ao longo de sua história, em diferentes momentos a Igreja demonstrou compaixão e solidariedade as pessoas que sofriam com catástrofes naturais/ambientais, pandemias, guerras, crises financeiras, fome". Portanto, a salvação de Deus acontece na prática da compaixão e solidariedade com os mais sofridos, levando a eles o conforto espiritual e o socorro material. 
Porém há necessidade de recriar ações pastorais que permitam essa proximidade das pessoas em tempos de pandemia. Na ação pastoral se requer recriar as práticas tradicionais: cultos, missas, atendimento, aconselhamento, atendimento a enfermos, pregações, pastoral da esperança às pessoas enlutadas, entre outros. Variadas ferramentas virtuais estão à disposição, além do celular e internet, as redes sociais como WhatsApp, Facebook, Instagram. Destaca Oliveira (2020, p. 263) que estamos num tempo de "poimênia digital", isto é, um serviço de cuidado pastoral através de meios modernos como "webinario", web conferência, lives realizadas por líderes de Igrejas, com vista a estabelecer uma comunicação próxima e cuidadosa das pessoas em tempo de confinamento. Observa-se de fato uma renovação muito grande e as Igrejas estão atentas às urgências pastorais e variados meios podem ser oferecidos:

1. Lives ou palestras sobre a família;

2. Aconselhamento pastoral virtual;

3. Pregações e mensagens;

4. Atendimento às mulheres que sofrem violência no lar:

5. Vídeos sobre cuidados paliativos;

6. Cultos on-line;

7. Aconselhamento a noivos na crise de adiar o casamento;

8. Catequese familiar.

É um tempo de crise, mas também de oportunidade de renovação. Porém é bom lembrar que as ferramentas digitais precisam ser usadas com sabedoria. Floristan (1993, p.179-180) lembra que a ação pastoral é criativa, crítica e transformadora. Vale lembrar a necessidade de uma contínua conversão pastoral para uma atitude de maior compaixão, uma prática mais samaritana como destaca a parábola do Samaritano (LC 10,30-37). Em um dos poucos documentos pontifícios dedicados ao tema do sofrimento: a carta SalvificiDoloris do Papa João Paulo II (1984, n. 30) comenta a revelação por parte de Cristo, sobre o sentido salvífico do sofrimento que não se identifica de forma alguma com a passividade. Antes pelo contrário é recusa da passividade perante o sofrimento: “O próprio Cristo é sobremaneira ativo. É assim que executa o programa messiânico da sua missão: O Espírito do Senhor está sobre Mim, porque me ungiu, para anunciar a Boa Nova aos 
pobres. Enviou-me para proclamar a libertação aos cativos, e aos cegos a recuperação da vista; a mandar em liberdade os oprimidos, a proclamar um ano de graça do Senhor" (Lc 4,18-19; cf. Is 61,1-2).

\section{Considerações finais}

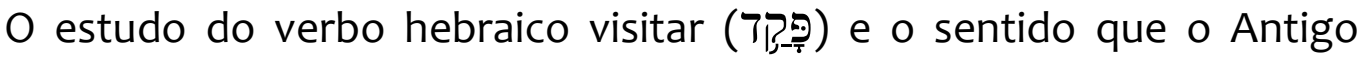
Testamento lhe dão é justamente o de caracterizar as visitas que Deus faz ao seu povo com caráter salvífico. Estas visitas revelam o modo de agir de Deus que escuta as dores e os clamores do seu povo e vem ao seu encontro com ações que beneficiam, salvam, restauram e trazem boas notícias. Com este

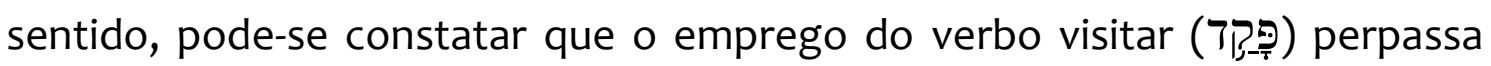
todas as etapas do Antigo Testamento.

É constatado também que algumas vezes a visita de Deus é caracterizada com o sentido de punição e juízo, porém nestes casos é para punir os dirigentes e líderes que desviam o povo do projeto de Deus e que não agem com cuidado como o pastor que devia zelar pelas ovelhas do rebanho.

As visitas salvíficas de Deus não se caracterizam por sinais extraordinários, mas em ações concretas, às vezes pequenas, que transformam a vida das pessoas beneficiadas. Deus age em vista da salvação e restauração e traz motivo de felicidade para o seu povo que agradece e reconhece a presença de Deus ao seu lado na sua caminhada. A visita de Deus pode também adquirir o sentido do cuidado, da cura, da proteção, da confiança diante do abandono e do refúgio confortável, ou então para trazer os benefícios para a terra, tornando-a fecunda e restaurando os estragos feitos pelos devastadores inimigos.

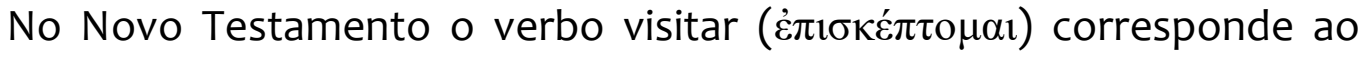

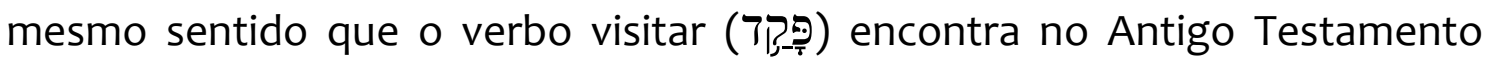
quando o sujeito é Deus. No Filho que se encarnou no meio de nós (Jo 1,14), temos a visita por excelência. O Cântico do Benedictus celebra a história passada, sobretudo recordando o Êxodo, e atualizando as visitas de Deus para os novos fatos salvíficos, profetizando a vinda próxima do Salvador: 
"Bendito seja o Senhor Deus de Israel porque visitou e redimiu o seu povo" (LC 1,68). Em Naim encontramos a melhor resposta de como o povo de Deus soube reconhecer as atividades de Jesus em favor do seu povo: "Um grande profeta surgiu entre nós e Deus visitou o seu povo" (LC 7,16). Ele agiu movido de compaixão por aquela pobre viúva.

Nesse tempo de pandemia, se faz sentir o exercício da "cidadania batismal" na corresponsabilidade de todos enquanto participantes de ministérios comuns de líderes, pastores, sacerdotes e profetas (cf. DOMEZI, 2020, p.13-14) colaborando nas ações sociais em favor do povo sofrido. Assim na práxis pastoral comprometida em defesa da vida e da justiça as Igrejas dão testemunho profético do "Deus conosco" (Mt 1,23), "Aquele que restaura a vida do povo" (cf. Ex 15,26).

\section{Referências}

AÇÃO Solidária da Igreja mobiliza comunidade em todo o país. Portal UNIFACC-MT, 29 abr. 2020. Disponível em: https://unifacc.com.br/acao-solidaria-da-igreja-mobilizacomunidades-em-todo-o-pais/. Acesso em: 03 mai. 2021.

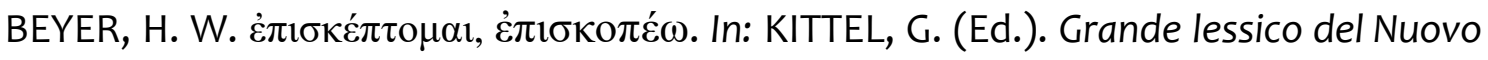
Testamento. Brescia: Paideia, 1979.

BOVON, F. El Evangelio según San Lucas (Lc 1,1-9,50). Salamanca: Sígueme, 2005. v. 1.

BOVON, F. El Evangelio según San Lucas (LC 19,28-24,53). Salamanca: Sígueme, 2010. V. 4 .

BROWN, R. E. Introdução ao Novo Testamento. São Paulo: Paulinas, 2004.

CENTRO EVANGELIZZAZIONE E CATECHESI "DON BOSCO". I quatro vangeli commentati: strumenti di lavoro per i gruppi biblici e per la preparazione della liturgia. Torino: Elledici, 2002.

CROATO, J. S. Isaías Vol. I: 1-39. O profeta da justiça e da fidelidade. São Leopoldo: Sinodal; Petrópolis: Vozes, 1989.

DOMEZI, M. C. Igreja no pós-covid-19. Vida Pastoral, São Paulo, ano 61, n. 336, p. $12-$ 20, 2020.

DUPONT, J. A ressurreição do moço de Naim (LC 7,11-16). Revista de Cultura Bíblica, São Paulo, v. 22, fasc. 85-86, p. 145-149, 1998.

FITZMYER, J. A. El Evangelio según Lucas. Madrid: Cristiandad, 1987. v. 2. 
FITZMYER, J. A. El Evangelio según Lucas. Madrid: Cristiandad, 2006. v. 4.

FLORISTAN, C. Teología prática, teoria y práxis. La acción pastoral. Salamanca: Sigueme, 1993.

FRANCISCO. Carta Encíclica Misericordiae Vultus. São Paulo: Paulinas, 2015.

FRANCISCO. Quando Deus visita. 16 set. 2014. Disponível em: <https://w2.vatican.va/content/francesco/pt/cotidie/2014/documents/papafrancesco-cotidie_20140916.html>. Acesso em: 15 out. 2016.

HARRIS, L. R.; ARCHER, G. L.; WALTKE, B. K. Dicionário internacional de Teologia do Antigo Testamento. São Paulo: Vida Nova,1998.

JENSEN, J.; IRWIN, W. H. Isaías 1-39. In: BROWN, R.; FITZMYER, J. A.; MURPHY, R. E. (Orgs.). Novo Comentário Bíblico São Jerônimo: Antigo Testamento. São Paulo: Academia Cristã, 2007.

JOÃO PAULO II. Salvifici Doloris. Paulinas: São Paulo,1984.

LÄPPLE, A. A mensagem dos Evangelhos hoje: para a leitura e o anúncio das Escrituras. São Paulo: Paulinas, 1971.

LÉON-DUFOUR, X.; DUPLACY, J.; GEORGE, A.; GRELOT, P.; GUILLET, J.; LACAN, M-F. Vocabulário de Teologia Bíblica.Petrópolis: Vozes, 1984.

MARTINS, P. Z. C. A visita de Deus: fundamentos bíblicos e ação pastoral. 2017. 104 p. Dissertação (Mestrado em Teologia) - Pontifícia Universidade Católica do Paraná, Curitiba, 2017.

MAZZAROLO, I. Lucas: A Antropologia da salvação. Rio de Janeiro: Mazzarolo Editor, 2004.

MCKENZIE, J. Dicionário Bíblico. São Paulo: Paulus, 1984.

MURPHY, R. E. Gênesis 25,19-50,26. In: BROWN, R.; FITZMYER, J. A.; MURPHY, R. E. (Orgs.). Novo Comentário Bíblico São Jerônimo. Antigo Testamento. São Paulo: Academia Cristã, 2012.

NOVO Testamento interlinear grego-português. São Paulo: Sociedade Bíblica do Brasil, 2004.

OLIVEIRA, M. D. de. Cuidado pastoral da Igreja em tempos de pandemia: Covid-19. Revista Caminhando, UMESP, v. 25, n. 1, p. 257-276, jan./abr. 2020.

OPORTO, S. G.; GARCÍA, M. S. Comentário ao Novo Testamento. São Paulo: AveMaria, 2006.

SCHÖKEL, L. A. Dicionário Bíblico Hebraico-Português. São Paulo: Paulus, 1997. 
SCHOTTROFF, W. Visitar. In: JENNI, E.; WESTERMANN, C. Diccionario Teologico. Manual Del Antiguo Testamento. Madrid: Cristiandad, 1978. Tomo II.

SPINETOLI, O. Luca: il vangelo dei poveri. Assisi: Cittadella, 1999. (Commenti e Studi Biblici).

RECEBIDO: $18 / 05 / 2021$

RECEIVED: 05/18/2021

APROVADO: 24/08/2021

APPROVED: 08/24/2021 